\title{
Vida como drama: repensando o papel do cliente em psicoterapia
}

\section{Life as drama: rethinking the role of the client in psychotherapy}

\section{Eloisa Nogueira Aguiar}

Universidade Estácio de Sá - UNESA, Resende, RJ , Brasil

\begin{abstract}
RESUMO
O artigo busca uma discussão sobre o papel do cliente em psicoterápica, a partir do pensamento de José Ortega y Gasset. Se a psicoterapia é a preocupação com a experiência vivencial, sua filosofia se oferece de grande valia, pois coloca a vida humana no centro de suas investigações. A vida é um projeto pessoal que implica, simultaneamente, as circunstâncias e a subjetividade. A vida requer um processo de "quefazer". Viver é sentir-se fatalmente forçado a exercitar a liberdade, a decidir quem vai ser neste mundo. Este é o caráter dramático da vida. Esta visão ajuda a explicar a sua negação afiada de uma essência humana. Assim, altera-se o papel do cliente, bem como sua expectativa em relação ao psicólogo.
\end{abstract}

Palavras-chave: Vida, Drama, Psicoterapia, Ortega y Gasset.

\begin{abstract}
The article searches a discussion about the role of the client in psychotherapy, from the thought of José Ortega y Gasset. If the psychotherapy is the preoccupation with the existential experience, his philosophy offers great value, therefore places human life in the center of his inquiries. Life is a personal project that entails both circumstances and subjectivity. Life requires a process of "quefazer". To live is to feel oneself fatally compelled to exercise liberty, to decide who we are going to be in this world. This is the dramatical character of the life. This view helps to explain his sharp denial of a human essence. Thus, the role of the client gets excited, as well as its expectation in relation to the psychologist.
\end{abstract}

Keywords: Life, Drama, Psychotherapy, Ortega y Gasset.

\section{I ntrodução}

[...] A chamada psicologia é uma dessas larvas que tomaram, no santuário, o lugar onde deveriam estar as imagens dos verdadeiros deuses (NOVALIS, 1799-1800/1992).

A epígrafe do poeta Novalis aponta a necessidade de um repensar a prática psicológica, principalmente quanto a um tipo de relação entre psicólogo e cliente, em que a interação necessária ao processo de 
ajuda não subestime a capacidade do cliente de se transcender, supervalorizando o saber e a técnica do especialista.

Em nosso entender, tomando a referida epígrafe como inspiração, a psicologia deveria dar conta do indeterminismo e da imprevisibilidade que caracterizam a existência humana. Entretanto, quantas não são as práticas psicoterápicas que se atam às identidades, aos estádios, às normas, às perícias, ao determinado, ao previsível e controlável? No viés dessas considerações, o filósofo espanhol José Ortega y Gasset (1883-1955) alerta-os para a compreensão do indivíduo a partir de sua inserção no mundo, na circunstância, ou seja, ele só pode ser realmente compreendido em sua singularidade, quando inserido na totalidade social e histórica que o determina e dá sentido à sua singularidade. A circunstância, portanto, é parte constitutiva daquilo que somos.

Nesse sentido, Ortega nos convida a pensar o homem com as coisas, ou melhor, transformando as coisas, porque viver é fazer algo; é escolher, dentro das inúmeras possibilidades que a circunstância apresenta, aquela que se aproxima da espontaneidade mais íntima da vida de cada um. Assim, para compreender o homem e a sua realidade devemos colocar a vida no centro da investigação, pois é nela que se manifestam todas as formas de experiência do real.

Sua filosofia aponta-nos para uma prática clínica pautada na experiência da vida, onde a vida é entendida como o que cada pessoa faz com a circunstância que se lhe apresenta. Ela, portanto, não é recepção do que se passa fora; ao contrário, é pura atuação, pois não nos é dada feita; cada um de nós tem de fazê-la para si, cada qual a sua. Diversamente aos demais entes, que tem seu ser já resolvido, prefixado, de antemão, como a pedra - pesar, gravitar para o centro da terra -, ao homem lhe é dada a imperiosidade de ter de estar sempre fazendo algo, sem indicações dos caminhos para seu atuar. Porque a circunstância, ou mundo, em que temos de viver, consiste em que sempre nos apresenta, dentro de seu círculo ou horizonte inexorável, uma variedade de possibilidades para a nossa ação; variedade diante da qual não temos outro remédio senão escolher e, portanto, exercitar a nossa liberdade, ou seja, não nos impondo uma única ação ou "quefazer, mas vários possíveis, deixando-nos dramaticamente entregues à nossa iniciativa e inspiração, à nossa responsabilidade" (ORTEGA, 1957/1973).

À psicoterapia, portanto, caberia a compreensão do quefazer humano diante do vazio que a vida apresenta, visando à flexibilidade das escolhas, a assunção das responsabilidades, tornando-se um espaço de abertura para o salto das escolhas espontâneas, imediatas, às reflexivas.

Com isso, a relação terapêutica retira a passividade cômoda do cliente diante de suas mazelas, convidando-o à participação ativa, a tomar as rédeas de seu quefazer vital, desmistificando o papel do 
especialista como ortopédico ou mágico. E também propicia ao psicólogo descer de seu "pedestal", aprendendo que a vida do outro, mesmo daquele que nos é íntimo, é para ele um mero espetáculo. A dor alheia é uma suposição, hipótese ou presunção nossa; não é realidade radical. A do cliente, no entanto, é inquestionável. É essa realidade radical o fenômeno que verdadeiramente interessa conhecer, pois nos informa a operacionalização do dramático quefazer, já que a vida (a de cada um), tal como vislumbrada por Ortega, é obra aberta, sem indicativos a priori. Partamos, portanto, à ampliação dessas questões.

\section{A idéia de vida: a realidade radical}

A idéia de vida é o ponto de partida da meditação de Ortega. Para ele, vida não é algo abstrato; ao contrário, viver é estar em contato com as coisas; é ocupar-se.

A noção de ocupação torna-se fundamental para a perspectiva com que o filósofo vai definir a vida, na medida em que, sendo ela nos dada vazia, temos, inevitavelmente, algo construir. Tem, dessa forma, um caráter súbito e imprevisível. Nesse sentido, para Ortega (1921/1998a), torna-se um erro acreditar que a vida seja simples operação receptiva, um mero transitar por entre as coisas, um sofrer passivo; ao contrário, ela é pura atuação. Afinal, diante do silêncio das coisas que o rodeia, o homem sente necessidade de lhes encontrar um sentido.

Assim, a vida tem que ir cada qual fazendo por si, instante por instante, em perpétua tensão de angústias e alvoroços, sem que nunca tenha a plena segurança sobre a eficácia dessa tarefa. Ela é, portanto, delícia, amargura e inumeráveis outras coisas e, precisamente porque é miriádica, não sabemos exatamente o que é. Podemos dizer, no máximo, que consiste em certo sabor - que Heidegger (1927/1989) chamou de Befindlichkeit ${ }^{1}$.

A "realidade radical" ou fundamental, então, é a vida concreta de cada um de nós, onde se encontra articulado tudo o que, para nós mesmos, tem significado, pois, sendo ela - a vida - nos dada vazia, devemos assumir os problemas que criamos para nós e para o que nos rodeia.

Por isso, a vida nos impõe a constante tarefa de descobrir as razões de tudo. A justificativa é a faina do eu. Daí o eu ser um projeto de vida e tornar a vida constitutivamente um drama, sempre luta frenética para conseguirmos ser de fato o que somos em projeto: “[...] a vida, individual ou coletiva, pessoal ou histórica, é a única entidade do universo cuja substância é perigo. Compõem-se de peripécias. É, rigorosamente falando, drama" (ORTEGA, 1929/1962, p. 136). E, para se compreender o caráter de dramaticidade que Ortega impõe à vida, é preciso um esclarecimento acerca do conceito de circunstância. 


\section{A circunstância: principal categoria da vida}

A noção de circunstância é essencial para o entendimento da ontologia orteguiana, e surge já em sua primeira obra, Meditações do Quixote (1914/1967), apontando que o Homem é um eu e a circunstância. Assim, a conhecida passagem "eu sou eu e minha circunstância", encontrada na referida obra, une os dois elementos eu e circunstância - de modo inseparável.

Como vimos, a realidade vital é a vida; eu estou aqui no meio de muitas coisas: sentimentos, idéias, valores, época, sociedade, com as quais permaneço em relação enquanto vivo. Eu e circunstância interagem e se completam.

Portanto, a vida é única e não se confunde com circunstância, pois não é pura recepção do que se passa em volta do eu (ORTEGA, 1922/1998b); é o que cada pessoa faz com a "circunstância": “[...] mesmo que fossem iguais os elementos da habitação, não seriam iguais as vidas de dois gêmeos univitelinos que vivessem juntos no mesmo local". Dito de outro modo, vida é realidade radical que aproxima eu e circunstância (CARVALHO, 2002, p. 71).

Ela é, pois, o resultado desta relação, mas não se confunde com ela; eu e circunstância só se deixam ver verdadeiramente na vida, que é a realidade concreta e real. Um dos principais, senão o maior estudioso da filosofia orteguiana esclarece este núcleo do seguinte modo:

\footnotetext{
Encontro-me, pois, desde logo, na vida, encontro-me vivendo, na vida encontro as coisas e me encontro a mim mesmo; isto é, a vida é o primário, é anterior as coisas e a mim, me é dada, sem suma, e tanto o eu como as coisas são secundárias a ela, ingredientes seus, realidades derivadas, ou, se se prefere, realidades radicadas nela, que é, ao contrário, a realidade radical (MARÍ AS, 1991; p. 27).
}

O conceito circunstância foi amadurecido e ampliado em seus cursos ministrados no período de 1916 a 1934, e reunidos nos ensaios de El Espectador (1998). Em Meditações do Quixote (1914), o conceito representa o entorno do corpo, coerente com a descoberta da ciência biológica que no seu tempo estuda o organismo num meio particular. Desde que publicou as Meditações, Ortega entendia circunstância como parte da realidade pessoal. Nos ensaios de El Espectador amadurece tal conceito, que usará nos últimos trabalhos das décadas de quarenta e cinqüenta.

A mudança significa a ampliação do sentido para além das sugestões da Biologia. O conceito alargado nestes ensaios maduros inclui 0 entorno ao eu, isto é, o meio exterior e as características do organismo: tanto físicas quanto psicológicas que envolvem o eu. Circunstância passa a ser tudo o que rodeia o eu: a realidade 
cósmica, a corporalidade, a vida psíquica, a cultura em que se vive, nela incluída também as experiências acumuladas no tempo. "O ambiente do homem e o próprio homem nesse ambiente constituem uma espécie de síntese" (CARVALHO, 2007, p. 125).

Esta é a forma orteguiana de entender circunstância. O conceito não representa o entorno cultural do homem, não é também o seu lado interior considerado separadamente da cultura, mas a interação entre eles. Ortega denominará "habitação" a circunstância que o "eu" reconhece como seu ambiente familiar.

Mas não há primazia de uma realidade humana interna pessoal, em detrimento de uma realidade externa, do mundo ou da circunstância, pois, para Ortega, pensar a vida, "minha vida" já é contar com suas circunstâncias e vice-versa. É esse o sentido de sua mais emblemática afirmação apresentada em Meditações do Quixote (1914).

Assim, vida, vida humana, só é e só pode ser no mundo, nas circunstâncias; por isso acrescenta em sua sentença um complemento de profunda importância: "[...] e se não salvo a ela, não salvo a mim" (ORTEGA, 1914/1967, p. 52); mundo é sensu stricto o que nos afeta. Portanto, a vida encontra-se sempre numa disposição em torno (circum) das coisas e demais pessoas. É decidir; é agir com o que está em torno.

Daí a necessidade de se compreender a "circunstância", revê-la, como também nos rever, ou seja, rever os sentidos que atribuímos a ela e que também por mim se fazem constituir problema. Por uma metáfora, Ortega nos ensina que, se alguém está se afogando, é na própria água em que se afoga que deverá buscar apoio para se salvar (ORTEGA 1958/1971 apud MOREJ ON, 1955).

Por isso, a circunstância, em seu pensamento, é o ponto de partida para toda a reflexão filosófica e, assim, também e principalmente, para a investigação sobre o ser do homem. Ela é um elemento essencial na constituição daquilo que o homem é, o que impede a concepção do homem como um ser ontologicamente independente.

Portanto, a circunstância, que a vida se lhe apresenta, impõe ao homem a tarefa de fazer-se, de realizar seu programa vital. Traduzse assim a concepção do homem como obra aberta - drama - que está a construir-se, em uma infinda tarefa de fazer-se no encontro com a realidade, ou seja, é pura instabilidade. No entanto, o homem tem uma missão de clareza, a qual "[...] não the foi revelada por um Deus, nem lhe é imposta de fora por ninguém e por nada. Leva-a dentro de si, é a raiz mesma de sua constituição" (ORTEGA, 1914/1967, p. 107).

Essa colocação retira do homem sua inoperância diante da vida e o incita ao exercício de sua liberdade e o coloca diante da responsabilidade pela configuração que dá às circunstâncias. Acreditamos que essa concepção torna-se fundamental para a clínica, 
na medida em que altera o papel do psicólogo como aquele que detém o poder da mudança.

Talvez não seja essa a expectativa do cliente em situação terapêutica, que espera ser "corrigido" por outro que não ele mesmo; cabe, então, à clínica a tarefa de desmistificar papéis, sendo abertura à salvação de si mesmo pelo sujeito. A clínica é ou deveria ser espaço para a revisão da união do sujeito com sua circunstância, na escuta atenta à dramaticidade que dela se anuncia, já que a vida não nos é presenteada com caminhos pré-determinados.

\section{Vida como drama ou o homem como autofabricação}

A vida não deve ser um romance dado a nós, mas um romance feito por nós. [...] Assim é toda vida uma história (NOVALIS, 1797-98/1988).

Essa epígrafe do poeta Novalis aponta-nos uma consideração que se aproxima do pensamento orteguiano, bem destacada em História como Sistema (1935/1982). Nesta obra, o filósofo aponta que, se é essencial ao ente humano estar sempre em situação e se o conteúdo ou determinação concreta da situação é a história, devemos concluir que o estar no mundo ou em circunstância é, essencialmente, estar na história.

Mais ainda, compreender o homem não consiste em prever sua conduta mediante o conhecimento antecipado das leis que, por hipótese, regem sua natureza, mas recolocá-lo em um contexto, em uma "circunstância", cujo principal ingrediente é o tempo. Compreender o homem é, portanto, restituí-lo à história, historializáIo (ORTEGA, 1935/1982). Vislumbra-se aqui mais um componente essencial à clínica: ater-se a uma história, aos caminhos e descaminhos do cliente. Apenas assim resulta inteligível uma realidade humana.

Afinal, como vimos, somos um eu e uma circunstância inseparáveis, e um eu histórico, envolvido numa circunstância também histórica. O entorno se transforma à nossa volta, as coisas mudam, temos história. Desde a infância o que está a nossa volta se altera: "No tempo que dizemos já vem a esta paisagem, a esta amizade, a este acontecimento, temos que ir preparando os lábios para dizer já se vão, já se vão" (ORTEGA, 1922/1998c, p. 247).

Mas será que o homem efetivamente contempla o mundo com 0 propósito de entendê-lo e o buscando compreender o que ele é fundamentalmente? Talvez a resposta esteja na grande procura por psicoterapias breves, que oferecem uma eficácia pontual e, não raras vezes, procedimentos técnicos no intuito de aliviar o sofrimento psíquico. Sem dúvida, em nosso tempo, essa questão pede 
esclarecimento, mas convém nela não nos atermos no momento para atingirmos o objetivo aqui proposto.

O que para nós importa é que em Ortega a relação inseparável entre o homem e sua circunstância não é algo inerte, exigindo ação, invenção, decisão e responsabilidade, elementos que compõem a estrutura da liberdade humana.

Iremos nos deter nestes elementos, já que traduzem o caráter do conceito de drama.

\subsection{A noção de liberdade e sua estrutura}

A liberdade aparece configurada, no pensamento orteguiano, em três momentos ou elementos fundamentais.

O de invenção traduz a carência de identidade constitutiva que conduz o homem à abertura de ter que constantemente criar a si próprio. Essa noção dá-se no solo no quefazer vital, no impulso à tarefa de fabricação de si mesmo. Traduz assim a concepção do homem como obra aberta - drama - que está a construir-se.

Essa tarefa de inventar-se a cada instante, de dar "forma" ao programa vital (ou projeto), não dispõe, como já mencionado, de um modelo pré-estabelecido; ao contrário, é prescrito apenas pela imaginação, na tentativa de eleger, entre as várias possibilidades, a que responda verdadeiramente o apelo do eu autêntico. Em outras palavras, não encontrando nenhuma identificação, ao invés de abrir mão do existir, o homem decide por conta própria inventar a sua vida, superando a condição natural de indeterminação.

É, portanto, a imaginação, a capacidade que o homem tem de entrar em contato consigo que o possibilita construir sua existência, diferenciando-se de todos os outros seres da natureza. Ortega denomina essa capacidade de ensimesmamento (ORTEGA, 1957/1973).

No ensimesmamento é a própria vida que se faz, totalmente permeada de imagens, situações que o próprio homem constrói, no desejo de construir a si mesmo e ao seu mundo, pois "se o homem não tivesse o mecanismo psicológico de imaginar ele não seria homem" (ORTEGA, 1942/1989, p. 47).

Através da imaginação, ele pode ver a realidade diferente do que ela é, e assim, transformá-la e adaptá-la aos seus desejos. A imaginação é fundamental neste processo, uma vez que assim, a vida pode ser entendida enquanto projeto.

No entanto, as situações humanas que se apresentam à clínica o quão difícil é o ser si mesmo. A vida fica descaracterizada, comparável à vida dos outros; o cliente reproduz regras préestabelecidas, considerando-as imutáveis e absolutas, fechando, dessa forma, a possibilidade de pensar a vida em sua radicalidade e autenticidade. Ortega usa o termo alteração. Neste sentido, as coisas acontecem de uma forma em que as pessoas não param para 
refletir sobre suas próprias ações, e acabam se anulando e abrindo mão de seu projeto de vida.

É tarefa, pois da psicoterapia, como um espaço favorável ao crescimento pessoal, oferecer ao cliente a abertura à intimidade consigo mesmo, e conseqüentemente de transformação, restabelecendo o processo formativo e criativo de cada um.

Para compreendermos a possibilidade dessa transformação, precisamos esclarecer a outra estrutura ou momento da liberdade: a decisão.

Existem dois modos de decisão em que o homem atua conforme sua personalidade: espontâneo, imediato; e o reflexivo. Do primeiro, temos as decisões que se realizam mecânica e subitamente. Do outro, encontramos o pensar meditativo, reflexivo, como fonte de eleição.

O que se apresenta na clínica é a incerteza frente às decisões, às escolhas. Adoraríamos, em nossa espontaneidade, sem grandes esforços, dar conta do que nos incomoda. No entanto, viver é um quefazer e sem caminhos apontados. Temos que inventar nossas possibilidades e, mais ainda, por elas nos responsabilizar.

O último momento, o da responsabilidade, é particularmente ético, no qual assumimos a autoria das decisões mediante o projeto individual que abarca o encontro e o trato com as circunstâncias. Sendo assim, a responsabilidade é absolutamente pessoal. Ser responsável é, sobretudo, assumir para si a decisão de ser "responsável por si", o que Ortega irá traduzir como sendo um préocupar-se, ou seja, ocupar-se por antecipação do seu projeto mais íntimo e autêntico, se opondo, assim, ao inautêntico modo de ser ou despreocupação.

Quantas vezes o cliente considera o mundo como um vilão, atribuindo a ele toda a responsabilidade pelas dificuldades que tem e esperando que o mundo lhe ofereça as condições mais adequadas para ele ser no mundo sem assumir a responsabilidade de suas escolhas e de seus caminhos.

Aí surge a oportunidade que a psicoterapia pode oferecer: de o cliente poder olhar, de novo, para o que foi vivido e passou ou não passou; para o que é vivido agora, e autenticar tudo como sendo dele, como sendo ele. Aqui se incluem as dores de que ele não quer se lembrar, suas perdas, culpas, faltas, desilusões, seu sentimento de impotência diante de um mundo que se torna cada vez mais ameaçador. Mas terapia também é o espaço para o cliente ver que essa é a vida que se realizou, e que pode ir a diferentes direções, quer dizer, novas escolhas, sem temer a possibilidade de mudanças radicais. Em suma, a psicoterapia é o espaço para a ressignificação da vida de forma diferenciada, reconhecendo como diz o poeta Brant em uma de suas composições: "se muito vale o já feito, mais vale o que será" (BRANT; MILTON, 1998). 


\subsection{A condição dramática e a possibilidade de superação}

Assim, a escuta e a intervenção psicoterapêuticas baseadas em pressupostos fenomenológico-existenciais, nos quais se insere Ortega, busca a reconfiguração da estrutura desse drama que se dispara entre o homem e o mundo.

Ao reconhecer que o modo de ser do homem apenas se exprime no comércio com o mundo, o filósofo madrileno deixou evidente a necessidade de modificá-lo. Se não salvo a circunstância não me salvo a mim. Mesmo ela facilitando ou empobrecendo as opções, se apressa em pedir para aceitarmos "[...] esse mundo de aljofre como matéria para fazer uma vida mais completa" (ORTEGA, 1958/1971, p. 192). Esse é o desafio humano: não viver a mesmice, alterando a circunstância ou sua forma de lidar com ela. $O$ homem tem 0 privilégio e a obrigação de escolher seu próprio ser, então, “[...] está condenado, queira ou não, a ser livre" (ORTEGA, 1957/1973, p. 51).

Por isso, para Ortega, a vida é construção de si mesma e construção do mundo em torno. E para o homem arquitetar seu próprio ser, a sua vida e o mundo é mister que ele se saiba e saiba o mundo que se abre. Entra em cena a atuação psicoterapêutica como espaço de favorecimento ao saber-se e conseqüentemente a novos olhares. A psicoterapia não é fórmula mágica e nem um mapa que possa nos levar ao tesouro, mas o lugar do enfrentamento do homem com ele mesmo, principalmente com aquilo que ele mais busca escapar, fugindo da responsabilidade diante da condução necessária da própria vida. Afinal, a vida humana é responsabilidade inalienável e intransferível: "[...] ninguém pode substituir-me na faina de me decidir, de decidir minha vida" (ORTEGA, 1942/ 1989, p. 33).

Original ou anônimo, diferenciado ou tosco, o homem tem que ser, bem ou mal, novelista da própria vida; tem que imaginar ou inventar o personagem que pretende ser.

Nossa presença na vida se parece ao que passaria a uma pessoa que, estando adormecida, é levada aos bastidores de um teatro e, ali, despertada por um empurrão, é lançada a toque de caixa diante do público: "agora atue!". Tem que inventar o papel, igual a nós com a invenção de nossa vida, sem nenhum guia pré-estabelecido. "Em linhas fundamentais, a vida é sempre imprevista. Não nos anunciaram antes de entrar em cena [...] não nos prepararam" (Ortega, 1958/1971, p. 168). Viver é, então, como uma tarefa, um problema que temos que resolver. A vida é mudança, possibilidade, projeto, programa, eleição, liberdade, tempo, história.

Assim, dada essa margem de indeterminação, um psicoterapeuta não pode chegar a captar com precisão o homem em totalidade; entretanto e apenas porque o cliente é livre, pode dar-se a possibilidade de uma mudança que é o que define a psicoterapia. 
Por ser liberdade, o homem é constitutivamente um drama, luta frenética para conseguir ser de fato o que é em projeto (ORTEGA, 1942/1989). Se o homem atuar autenticamente, em vista da realização de seu projeto, as circunstâncias deixam de lhe surgir como obstáculos ou intervenções adversas para se tornarem condições e instrumentos da vida pessoal. Mas, a partir do momento em que não se lança a responder aos seus desafios, experimenta problemas psicológicos, perde horizonte.

Daí se depreende que "drama" é, frente às coisas: incessante quefazer; insegurança de alcançar aquilo que com o fazer se persegue. "A vida, a nossa vida, é, pois, um problema que necessitamos resolver nós" (ORTEGA, 1958/ 1971, p. 168).

Com essa afirmação Ortega dota o homem "[...] de uma atitude eticamente otimista por estar a vida aberta à transcendência" (GONZÁLEZ, 2001, p. 18).

É justamente essa "abertura" o que incomoda as pessoas. Como bem questiona Sartre ([1946]1987, p. 4), com quem Ortega mantém afinidades de pensamento, "será que, no fundo, o que amedronta na doutrina que tentarei expor não é o fato de que ela deixa uma possibilidade de escolha para o homem?". E acrescenta: "O que as pessoas, obscuramente, sentem, e que as atemoriza, é que o covarde que nós lhe apresentamos é culpado por sua covardia. "[...] O que as pessoas querem é que nasçamos covardes ou heróis" (SARTRE, 1946/1987, p. 14).

Ortega certamente concordaria com Sartre que o que aflige as pessoas é saberem-se responsáveis pelos caminhos que têm traçado. E também concordaria que não se tratam de colocações pessimistas, mas necessárias para uma reflexão sobre nossas desculpas frente às nossas questões. É a liberdade, privilégio humano, transformando-se em fardo.

O que está em jogo nestes filósofos tão afinados conceitualmente, é que o coeficiente de adversidade das coisas, em particular, não pode constituir argumento, desculpa, contra nossa liberdade, porque é "por nós" que surge a fatalidade. Um exemplo:

Determinado rochedo, que demonstra profunda resistência se pretendo removê-lo será, ao contrário, preciosa ajuda se quero escalá-lo para contemplar a paisagem. Em si mesmo se for sequer possível imaginar o que ele é em si mesmo -, o rochedo é neutro, ou seja, espera ser iluminado por um fim de modo a se manifestar como adversário ou auxiliar (SARTRE, 1943/1997, p. 593-594).

Assim, mesmo diante das limitações, das porções de fatalidade da vida sempre haverá uma margem de decisão à vida, uma possibilidade de solução. 
Porque a vida está constituída de um lado pela fatalidade, mas de outro pela necessária liberdade de decidir-nos diante dela, há em sua própria base matéria para uma arte, e nada a simboliza melhor que a situação do poeta que apóia na fatalidade da rima e do ritmo a elástica liberdade de seu lirismo (ORTEGA, 1958/1971, p. 189).

A perspectiva existencialista do raciovitalismo de Ortega é, efetivamente, um esforço para mostrar a transitividade do ser, o ser como ser possível. Aliás, em árabe, por exemplo, o verbo ser é transitivo (envolve ação). Afinal, viver "[...] é, acima de tudo, uma revelação, um não contentar-se com ser, mas compreender ou ver que se é, um inteirar-se. É a descoberta incessante que fazemos de nós mesmos e do mundo em torno" (Ortega, 1958/1971, p. 165).

É por isso que minha questão não é problemática para ninguém, mas apenas para mim. Se atribuo a algo algum dilema, deve-se, então, exclusivamente a mim retirar-lhe o sentido de agravo ou, pelo menos, confrontar-me com aquilo sobre o qual atuei e traduzi.

Por isso nossa vida, a "minha vida", não pode encontrar sua resposta num mecanismo de funcionamento mental, num aparelho psíquico abstrato que determinaria minhas ações. "Minha vida não é o ocorre em minhas células como não é o que ocorre em meus astros, nesses pontinhos de ouro que vejo em meu mundo noturno" (ORTEGA, 1958/1971, p. 164).

Minha vida, essa realidade fundamental, justamente por ser fundamental - e fundante -, não é uma "coisa" entre as demais, assim como não possui uma substância previamente dada, mas será o que dela nós fizermos, no curso de nossa existência. Por isso é "drama".

[...] É drama porque não se faz sem interrogação e angústia. A faceta dramática da vida provém, assim, de sua própria estrutura. Se o homem fosse um ser estático, se a vida humana, em vez de ocupação e preocupação, fosse crescimento espontâneo "natural", encontrar-se-ia liberta de problemas e de perplexidade (PINA PRATA, 1962, p. 322).

Drama não é uma coisa que está aí - não é em nenhum bom sentido uma coisa, um ser estático -, mas o drama passa, acontece, exige atuação.

Afinal, o homem para Ortega se define por sua ação, por seus atos; e, o que define o teatro, pelo menos o teatro ocidental, o teatro que nós conhecemos, é a ação; os personagens têm uma ação a cumprir. A própria palavra drama, uma palavra grega, significa ação. A ação dramática tem uma harmonia com a ação propriamente dita, a ação tout court. O homem não é uma "res cogitans", mas uma "res dramática"; um drama, uma unidade dramática do eu e mundo, ou seja, do eu e sua circunstância. 
E, tal como a ação do personagem no palco, no mundo, tem uma ordenação própria, dentro de cada vida, as coisas se ordenam em uma perspectiva rigorosa e mutante, assumem diversas funções ou papéis, em uma hierarquia precisa, cujo princípio é interno a essa vida, e não coincide com a que uma consideração exterior suporia.

As coisas me "levam" segundo sua importância, e em um sentido determinado que para mim tenham, por sua significação - por isso a vida é interpretação de si mesma e de seus conteúdos.

Por isso, não devemos esquecer que o que nos é relatado no setting clínico não passa de um espetáculo que apenas é assistido, mas não vivido. E que a dor alheia não seja compreendida pela medida de uma dor suposta em nós ou retratada nas linhas abstratas de um teórico de gabinete.

Daí, para Ortega (1929/1962 apud SANTOMÉ, 1998, p. 61), ser o especialista, o "doutor",

[...] aquele que sabe tudo o que é preciso saber para ser um personagem discreto, conhece apenas uma determinada ciência, e mesmo desta ciência conhece apenas a pequena parcela que pesquisa ativamente. Chega a proclamar como virtude o fato de não saber nada que fique de fora da estreita paisagem que cultiva especialmente e chama de diletantismo a curiosidade pelo conjunto do saber.

Portanto, cabe ao psicólogo descer de seu pedestal, a fim de que o cliente vislumbre-se como ator principal do drama da vida, como agente encarregado da própria biografia, compartilhando, ao mesmo tempo, da experiência da criatura e do criador. Desse modo, seu quefazer indispensável e intermitente se abre a novos caminhos, a novas reconfigurações.

Além do mais, é o futuro que move o homem. Dito isso, inverte-se a compreensão que impregna o senso comum onde o que motiva a ação é a constatação da situação atual do mundo, o presente em sua plenitude. Mas, ao contrário, os motivos que exigem nossa ação não são o estado atual das coisas, mas a concepção de outro estado das coisas que ainda não existe, ou seja, quando um futuro possível ilumina nossa situação atual é que somos puxados para agir.

A situação presente por mais difícil que seja não designa por si mesma a ação. Os motivos que levam à ação não são o sofrimento e as dificuldades presentes, ao contrário, somente desde o momento em que concebemos como possível outro estado das coisas, é que o futuro ilumina a situação atual e agimos. A ação é uma projeção do homem para algo que ainda não é. Nossa relação com o mundo é infestada pelo futuro.

Assim, somente ao atender à dinâmica que a vida lhe cobra, pode o cliente extrair o sentido verdadeiro para as suas ações, ou seja, o ater-se autêntico. Fora isso, resta apenas o agir naufragado na 
multiplicidade das coisas, distanciado do próprio ser e ancorado na vaidade do psicólogo, por exemplo.

\section{Considerações finais}

O pensamento de Ortega altera o rumo da indagação do que seja a realidade, ou o modo de considerar a razão de ser de tudo. Formulando um pensamento distinto do realismo antigo e do idealismo moderno, postula que não podemos pensar o mundo sem o Homem e nem este à parte do mundo.

Ao abrir a compreensão da existência para um diálogo com a cultura e com o tempo, o filósofo nos fala da responsabilidade com o mundo a ser criado por nossas vidas. Sua filosofia contempla a responsabilidade de construir uma existência pessoal num mundo sem garantias e perigoso, numa história sem sentido prévio. Viver é abrir-se ao contato com os outros homens e com as coisas, é sair de si mesmo, é arriscar-se na construção do futuro. Sua filosofia inova a forma de pensar, colocando o fundamento na vida e transformando-a numa realidade capaz de alterar as circunstâncias e realizar a vocação de cada homem.

Desse modo, encontramos em Ortega um convite a repensarmos nossa postura clínica diante do outro, entendendo-o como sujeito que constrói sentidos num determinado mundo e num certo momento das suas histórias. Como sujeito e história são indissociáveis, os sofrimentos psíquicos que chegam à clínica demonstram as estratégias existenciais que os sujeitos estão utilizando para tentar dar conta de modos de subjetivação.

Como o homem é ele e suas circunstâncias, não se torna possível pensá-lo identificando essências ou estruturas que determinem seu modo de ser no mundo, aprisionando e objetivando-o em teorias, técnicas ou conhecimentos a priori.

A ação clínica deve, pois, dedicar-se a colocar em andamento o que já é próprio do humano, ajudando-o a pró-curar aquilo de que foge: a morada no sentido e o habitar des-cobrindo ele mesmo e o mundo, relançando-o na sua existência, a fim de que pense a própria vida.

Portanto, a ação clínica assim compreendida rompe com o modo de contato construído numa concepção técnico/explicativa, constituindose numa disponibilidade para acompanhar o outro (cliente) em seu cuidar das suas possibilidades mais próprias, dispondo delas livremente e com responsabilidade.

Por outro lado, não restam dúvidas de que o referencial teórico do psicólogo clínico constitui-se numa das ferramentas com as quais ele constrói o espaço da clínica.

Porém, ao mesmo tempo em que necessita desse referencial para visualizar a queixa, problema ou sofrimento do indivíduo, ele precisa se afastar desse mesmo referencial para poder enxergar a 
singularidade do sujeito, sem correr o risco de impor o seu saber sobre ele.

Tal modo de pensar nos faz considerar a subjetividade como um espaço individual cujas significações sociais constituem a história pessoal desse sujeito e os sentidos que ele atribui ao mundo.

Pois bem, lançado num processo criador, o homem tem a capacidade não apenas de inventar a sua vida, mas, também, de transformar a circunstância para que sua tarefa se torne viável. Assim, torna-se imprescindível que o cliente assuma sua solidão, seu "ensimesmamento", que se veja juiz de seu quefazer, intérprete de seu exercício inevitável de liberdade no mundo. Desta forma, se deparará com o mundo como um puro possível que deve ser construído e desvelado incessantemente em conformidade com as necessidades emersas. E, neste processo de co-descoberta, estará pronto para ter uma atitude autêntica perante o mundo. Uma atitude em que ele poderá descobrir o princípio que leva à arte e à filosofia. Princípio este em que, embora o mundo se prenda a uma determinação cabal, ele não se prende a elas, abrindo-se sempre a novas possibilidades. Concluímos então, que o princípio da arte, do fazer filosófico e da vida autêntica é o mesmo.

Concordamos com o filósofo Galimberti (2006) ao considerar a psicologia a "mais platônica das ciências", propondo, com radicalidade, uma refundação da psicologia, que deverá assumir como seu ponto de partida, não o sujeito psicológico, portador de um abstrato aparelho psíquico, nem o objeto psíquico, mas a ação humana.

Assim, a clínica, como espaço da discussão da experiência de vida, muito tem a se enriquecer com as lições de Ortega que, em nenhum momento descuidou-se em alertar que a vida:

\footnotetext{
“[...] não é recepção do que se passa fora, antes pelo contrário, consiste em pura atuação, viver é interior, portanto, um processo de dentro para fora, em que invadimos o contorno com atos, obras, costumes, maneiras, produções segundo estilo originário que está previsto em nossa sensibilidade" (ORTEGA, 1922/1998, p. 378).
}

Se estivermos interessados numa volta à vida, no encontro com o humano do humano, e não na reificação das representações, ou em um abstrato aparelho psíquico, teremos que repensar formas de ajuda que melhor contemplem o cliente como um todo e diante de seu "quefazer" dramático.

\section{Referências Bibliográficas}

BRANT, F.; NASCIMENTO, M. O que foi feito deverá. In: NASCIMENTO, M. Tambores de Minas: ao vivo. [S.I.]: Warner Music, 1998. 1 CD, faixa 1. 
CARVALHO, J. M. de. Introdução à filosofia da razão vital de Ortega y Gasset. Londrina: CEFIL, 2002.

O homem e a filosofia: pequenas meditações sobre a existência e a cultura. Porto Alegre: EDIPUCRS, 2007.

GALIMBERTI, U. Psiche e techne: o homem na idade da técnica. São Paulo: Editora Paulus, 2006.

GONZÁLEZ, L. J. F. A gratuidade na ética de Ortega y Gasset. São Paulo: Annablume/Fundação Rio Madeira, 2001.

HEIDEGGER, M. Ser e tempo. Petrópolis: Vozes, 1989.

MARÍAS, J. Acerca de Ortega. Madrid: Espasa Calpe, 1991.

NOVALIS, F. H. Pólen: fragmentos, diálogos, monólogo [1797-1798]. São Paulo: Iluminuras, 1988, p. 158-159.

$\overline{1} 2 \overline{1}$.

Fragmentos de Novalis. Lisboa: Assírio \& Alvim, 1992, p.

ORTEGA Y GASSET, J. A rebelião das massas. Rio de Janeiro: Livro Ibero-Americano, 1962.

$\overline{1} \overline{9} \overline{6} \overline{.}$

Meditações do Quixote. São Paulo: Livro Ibero-Americano,

$\overline{1} \overline{7} \overline{1}$.

Que é filosofia? Rio de Janeiro: Livro Ibero-Americano,

O homem e a gente: inter-comunicação humana. Rio de Janeiro: Livro Ibero-Americano, 1973.

Brasília, 1982.

História como sistema. Brasília: Editora Universidade de Vozes, 1989.

Em torno a Galileu: esquema das crises. Petrópolis:

. Para un museo romántico. In:

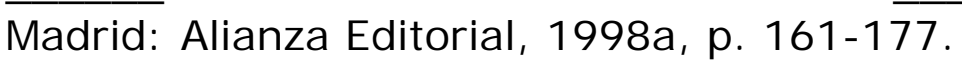

EI espectador VI

Temas de viaje. In:

EI espectador IV. Obras

completas. v. II. Madrid: Alianza, 1998b, p. 367-82.

De Madrid e Asturia o los dos paisajes. In:

Espectador III. Madrid: Alianza Editorial, 1998c, p. 53-93.

PRATA, F. X. P. Dialética da razão vital: intuição originária de José Ortega y Gasset. Lisboa: Livraria Morais, 1962.

SANTOMÉ, J. T. Globalização e interdisciplinariedade: o currículo integrado. Porto Alegre: Artes Médicas, 1998.

SARTRE, J-P. O existencialismo é um humanismo. São Paulo: Nova Cultural, 1987.

Petrópolis: Vozes, 1997.

VATTIMO, G. Introdução a Heidegger. Lisboa: Instituto Piaget, 1996. 


\section{Endereço para correspondência}

Eloisa Nogueira Aguiar

Universidade Estácio de Sá, Campus Resende, Rua Zenaide Vilela, s/n, Jardim Brasília, CEP 27515-010, Resende - RJ, Brasil

Endereço eletrônico: eloaguiar@zipmail.com.br

Recebido em: 24/03/2010

Reformulado em: 28/05/2010

Aceito para publicação em: 31/05/2010

Acompanhamento do processo editorial: Deise Mancebo

\section{Notas}

${ }^{1}$ No $§ 29$ de Ser e Tempo (1927/1989), Heidegger discorre a respeito do que vem a ser a disposição e explicita que ela é um modo existencial básico em que o ser-aí é o seu aí, isto é, o Dasein é o seu Da. Para o filósofo alemão, o Dasein é na medida em que, como ser-no-mundo, interage com o mundo. Devemos sublinhar que a disposição é um dos existenciais básicos, um aspecto constitutivo de estar aberto ao mundo do Dasein. O termo disposição é tradução - na versão brasileira de Ser e Tempo - do termo alemão Befindlichkeit. O filósofo e comentador de Heidegger, Gianni Vattimo, traduz o termo para "situação afetiva" (1996, p. 37). Segundo Vattimo, o termo "quer dizer o modo de se 'encontrar', de se 'sentir' desta ou daquela maneira, a 'tonalidade afectiva' em que nos encontramos" (1996, p. 37).

${ }^{2} \mathrm{~A}$ referência de Ortega à "vida humana" merece um esclarecimento: "Sempre que digo 'vida humana', seja o que for, a não ser que eu faça alguma especial restrição, evite-se pensar na vida de outro, e cada um deve referir-se à sua própria e tratar de tê-la presente. Vida humana como realidade radical é somente a de cada um, é somente a minha vida. Para comodidade de linguagem, algumas vezes a chamarei de 'nossa vida', mas deve sempre entender-se que, com essa expressão, me refiro à vida de cada um e não à dos outros, nem a uma suposta vida plural e comum" (ORTEGA, 1957/1973, p. 78). Com isso quer dizer que a dor alheia não aparece em "minha vida" como realidade radical, mas apenas como realidade secundária (1957/1973, p. 78). 